\author{
Zofia Okraj \\ Uniwersytet Jana Kochanowskiego w Kielcach \\ E-MAIL: zofiaokraj@gazeta.pl
}

\title{
O konferencji „Sto pytań o kreatywność”, czyli dlaczego warto angażować studentów w działania naukowe i organizacyjne
}

\section{STRESZCZENIE}

Artykuł zawiera sprawozdanie z konferencji naukowej „Sto pytań o kreatywność” oraz analizę powodów, dla których warto zachęcać i angażować studentów w organizację różnych inicjatyw naukowych. W takich formach aktywności studenci i nauczyciele akademiccy stają się realnymi partnerami w procesie nabywania wiedzy i doświadczeń. Takie działania to nie tylko szansa na prawdziwą kreatywność i wieloaspektowe transgresje, ale również przykład wielkiej i niepodważalnej wartości i tradycji, jaką jest wspólnota uniwersytecka.

SŁOWA KLUCZOWE: konferencja naukowa, kreatywność, współpraca studenci - nauczyciele akademiccy.

\section{Wstęp}

W tekście podejmuję refleksję nad uwarunkowaniami i wartościami inicjatyw naukowych, realizowanych wspólnie przez nauczycieli akademickich i studentów. Uczynię to na przykładzie działań ze studentami w czasie przygotowań i realizacji Ogólnopolskiej Konferencji Naukowej „Sto pytań o kreatywność", która odbyła się 23 kwietnia 2015 roku na Uniwersytecie Jana Kochanowskiego w Kielcach. Opisywane działania można traktować jako antytezę wobec głosów o kryzysie wspólnotowości jako wartości Uniwersytetów ${ }^{1}$. W realiach życia akademickiego uwikłanego w problemy związane z komercjalizacją, biurokratyzacją, obawami o ciągłość zatrudnienia, realizacją odgórnie ustalonych efektów kształcenia itp. warto wziąć pod uwagę to, że

Por. E. Bochno, Relacje w grupie studenckiej, [w:] Oblicza kapitału społecznego uniwersytetu: diagnoza, interpretacje, konteksty, M. Dudzikowa i zesp. (red.), Oficyna Wydawnicza Impuls, Kraków 2013, s. 44-45; P. Sztompka, Uniwersytet wspótczesny: zderzenie dwóch kultur, [w:] Idea uniwersytetu: reaktywacja, P. Sztompka, K. Matuszek (red.), Wydawnictwo Uniwersytetu Jagiellońskiego, Kraków 2014, s. 17-32. 
niosąca postęp w edukacji emancypacja myślenia i działania to nie tylko tropienie i nagłaśnianie irracjonalnych, antytwórczych i „nieżyciowych” przepisów oraz rozporządzeń, ale również - a może dzisiaj należałoby powiedzieć przede wszystkim - poszukiwanie tego, co ma i nadaje sens istnienia Uniwersytetom i tworzącym je (mimo wszystko) wspólnotom.

\section{Geneza inicjatywy, „demotywatory” i przykłady realnych transgresji}

Inicjatywa Konferencji Naukowej „Sto pytań o kreatywność” zrodziła się w listopadzie 2014 roku podczas spotkania Koła Naukowego Studentów Wydziału Pedagogicznego UJK „Strefa Twórczych Dyskusji”. Planując działania na 2015 rok, studenci uwzględnili wśród nich organizację konferencji, ale ze wskazówkami, że „ma być inna, taka na której nie trzeba będzie mówić, na której nie będzie nudno...”. Z tych i innych wizji przyszłej konferencji wyklarował się obraz spotkania naukowego poświęconego zagadnieniu „kreatywności”, ale w oparciu o autentyczne pytania wokół tego tematu, nurtujące studentów. W styczniu 2015 roku członkowie „Strefy...” oraz studenci II roku pedagogiki UJK różnych specjalności zostali poproszeni o zapisanie pytań dotyczących kreatywności. W zamierzeniu - ze względu na klarującą się nazwę konferencji - miało być ich około 10o. Okazało się, że w ciągu kilku godzin zebrano ich ponad 230. Pytania zostały zaklasyfikowane do 12 kategorii tematycznych: kreatywność-terminy, kreatywność a: osobowość; dydaktyka; wychowanie; praca socjalna; doradztwo zawodowe; praca; samokształcenie; praca z osobami niepełnosprawnymi; resocjalizacja; badania oraz kreatywność nauczyciela. „Niesklasyfikowane” pytania zgrupowano w kategorii „inne”. Sporządzona przez studentów lista „niewiadomych” była imponująca, pojawiały się też kolejne pytania - o sposób organizacji konferencji, o budżet, o prelegentów i wiele innych. Również na tym etapie pojawiły się demotywujące do działania wypowiedzi osób zapoznających się z planami konferencji, np. „Będziesz za to miała tylko 1 punkt...”, „Kto odpowie na te pytania?”, „Kto za to zapłaci?”, „Pytania trzeba ocenzurować - są nieprofesjonalne...”, „Nic ciekawego nie ma w tych pytaniach...”, „Kreatywny nauczyciel - nudy - kto tego będzie słuchał?” itp. Co ciekawe, żadna z tych wątpliwości nie wyszła od studentów..., natomiast prawie wszystkie były wspólnie z nimi rozwiązywane. Wiele z tych rozwiązań nosiło znamiona transgre-

2 Do głównych celów statutowych Studenckiego Koła Naukowego „Strefa...” należy poszerzanie wiedzy dotyczącej kreatywności/twórczości, wielotorowe stymulowanie twórczego myślenia i działania studentów oraz rozwijanie umiejętności dyskutowania klasycznego i twórczego - ukierunkowanego na rozwiązywanie różnego rodzaju problemów. 
sji związanych nie tylko z odrzuceniem krytyki konferencji a priori, która jak sądzę - wynikała $\mathrm{w}$ wielu przypadkach również z zastosowania niekonwencjonalnych (a zatem często budzących opór) rozwiązań. Zgodnie z przyjętą konwencją studenci - autorzy pytań o kreatywność - stali się inspiratorami wystąpień, współdecydującymi wraz z prelegentami o ich treści, która w tym przypadku nie była „narzucona”, ale wyczekiwana, wynikająca z odczuwanych wątpliwości i niejasności, jakie pojawiają się w kontekście refleksji o kreatywności. Ostateczny bilans działań przygotowawczych był pozytywny. Niemal wszyscy zaproszeni prelegenci przyjęli propozycję wzięcia udziału $\mathrm{w}$ „niekonwencjonalnej” konferencji. Wielu z nich doceniło autentyczność pytań studentów, a prof. dr hab. Krzysztof J. Szmidt dopisał do tej listy również swoje propozycje kolejnych pytań... Dla zaproszonych prelegentów, którzy chcieli wziąć udział w konferencji, ale wiedzieli, że nie będą mogli tego dnia przyjechać do Kielc, przygotowano opcję prezentacji przez Skype’a (rozwiązanie zastosowane przy kilku prelekcjach po raz pierwszy podczas konferencji naukowej w Instytucie Pedagogiki i Psychologii UJK). Postanowiono, że konferencji będą towarzyszyć warsztaty twórczej dramy prowadzone przez dr Kamilę Witerską z AHE w Łodzi (pierwsza tego typu inicjatywa zrealizowana przez i dla Koła Naukowego UJK). Ze względu na ograniczone możliwości czasowe, konfrontowane z zamierzeniem udzielenia odpowiedzi na „sto pytań o kreatywność", blok prelekcji został wzbogacony o sesję posterów pisemnych, graficznych i przestrzennych, których treści również budowane były wokół pytań zgłoszonych przez studentów (pierwsze - na taką skalę rozwiązanie podczas konferencji organizowanej w UJK).

Co by było, gdybyśmy uwierzyli - zgodnie z treścią "demotywatorów” - że nie da się takiej inicjatywy wprowadzić w życie? Zapewne tak właśnie by się stało. Przyjmując jednak postawę transgresji ${ }^{3}$ - wiążącą się z pokonywaniem barier i ograniczeń oraz progresywnym przesuwaniem granic tego, co wspólnie możemy zdziałać - zamieniliśmy ideę w działanie przynoszące pozytywne efekty. Ostatecznie w konferencji wzięli udział wykładowcy, doktoranci i studenci z 11 szkół wyższych. Wystąpień wysłuchało łącznie kilkaset osób, a w galerii posterów znalazło się ponad 60 różnych prezentacji o kreatywności i bliskich jej zagadnieniach.

Transgresje: „czyny i akty myślenia polegające na przekraczaniu granic dotychczasowych doświadczeń i osiągnięć materialnych, społecznych czy intelektualnych, na wykraczaniu poza to, czym człowiek jest i co posiada. To przełamywanie granic, które dotąd nie zostały przekroczone, stosowanie nowych, odważnych rozwiązań w różnych sferach życia”, J. Kozielecki, Psychotransgresjonizm: nowy kierunek psychologii, Wydawnictwo Akademickie Żak, Warszawa 2007, s. 39. 


\section{Prelekcje}

W sesji plenarnej udział wzięło trzynastu prelegentów, trzech z nich skorzystało z opcji prezentacji przez Skype’a. Każde wystąpienie poprzedzone było odwołaniami do pytań, które stanowiły inspirację do przygotowania danej prelekcji. Jako pierwsza głos zabrała prof. dr hab. Irena Pufal-Struzik z UJK w Kielcach - Kierownik Naukowy Konferencji. W prezentacji KreATYWNOŚĆ A INNE CECHY OSOBOWOŚCI CZŁoWIEKA słuchacze mogli zapoznać się z różnicami między kreatywnością - zawierającą się głównie w pomysłowości myślenia i działania - a twórczością, związaną z powoływaniem do życia rozwiązań nowych (subiektywnie lub obiektywnie), wartościowych, zastosowalnych, oryginalnych itp. Interesująca dla słuchaczy była również podnoszona w wielu pytaniach - klasyfikacja cech charakteru typowych dla osób twórczych, takich jak: autonomia, nonkonformizm, skuteczność i elastyczność postępowania, duża aktywność, wytrwałość, stanowczość, upór w pokonywaniu przeszkód i sytuacji trudnych, śmiałość, pracowitość, bezpośredniość, pewność siebie, niezależna skala wartości itp.

$\mathrm{O}$ istocie, rodzajach i uwarunkowaniach kreatywności mówił również prof. dr hab. Krzysztof J. Szmidt z UŁ w Łodzi. W entuzjastycznie przyjętym przez studentów wystąpieniu pod tytułem CZY KREATYWNOŚĆ JEST OGÓLNA, CZy SPeCyficzNa? O TyM, DlaCZego John Baer nie dostrzega Stefana KISIELEWSKIEGo...?, prelegent odwoływał się do różnych aspektów działań podejmowanych przez osoby kreatywne i twórcze, ukazując niejednokrotnie złożoność ich drogi życiowej, ocenianej w kategoriach różnych wymiarów twórczości. Wiele poruszonych w tym wystąpieniu kwestii odnosiło się do zgłoszonych przez studentów pytań. Na niektóre z nich ekspert polskiej pedagogiki i dydaktyki twórczości nie odpowiedział wprost, ale pozostawił słuchaczom pole do własnego, osobistego poszukiwania odpowiedzi, a przy tym również do refleksji, iż bycie arbitrem w kwestiach, czy on/jego działanie jest twórcze, nie jest wcale zabiegiem prostym i nie da się go ograniczyć wyłącznie do badania testowego, które nie uwzględnia wielu czynników i kontekstów ludzkiego działania.

Profesor dr hab. Teresa Giza z WŚ w Kielcach przedstawiła w swoim wystąpieniu różnice i relacje między „kreatywnym nauczycielem a nauczycielem kreatywności”. Kim jest kreatywny nauczyciel? Osobą pomysłową, odważnie sięgającą po innowacyjne rozwiązania organizacyjne i metodyczne, pokazującą uczniom - przede wszystkim swoimi działaniami - istotę postawy twórczej, związanej także z poszukiwaniem rozwiązań wobec różnego rodzaju problemów. Kim jest nauczyciel kreatywności? Osobą, która poprzez zróż- 
nicowane działania stymuluje i rozwija kreatywność uczniów, zachęcając ich do poszukiwania, werbalizowania i wcielania w życie pomysłów i projektów.

W kolejnej prelekcji pod tytułem KREATYWNośĆ „W CUDZYCH BUTACH”. W JAKI SPOSÓB DRAMA ROZWIJA TWÓRCZE MYŚLENIE I DZIAŁANIE?, dr Kamila Witerska z AHE w Łodzi zaprezentowała istotę, rodzaje i protwórcze uwarunkowania zajęć z dramy. Wystąpienie to stanowiło preludium do odbywających się tego samego dnia warsztatów dla studentów pod hasłem: „Drama: kreatywne budowanie i zmiana relacji”.

O twórczym podejściu w nagradzaniu i karaniu mówiła mgr Monika Domon z Poradni Psychologiczno-Pedagogicznej w Kielcach. W swoim wystąpieniu zwróciła uwagę na potrzebę pomysłowości w doborze metod wychowawczych, podkreśliła także znaczenie więzi z wychowawcą jako istotnego czynnika warunkującego skuteczność pozytywnych i negatywnych wzmocnień.

Z kolei dr Katarzyna Marszałek z UKW w Bydgoszczy zaprezentowała przez Skype'a wystąpienie pod tytułem PraCowniK SOCJALnY - ZAWóD WYMAGAJĄCY KREATYWNOŚCI? Wychodząc od ustaleń terminologicznych, prelegentka podała następnie przykłady antykreatywnych działań wobec osób potrzebujących wsparcia. Autorka wystąpienia wskazała, iż wśród pracowników socjalnych potrzebny jest moduł twórczej pracy rozwijającej się wokół pytania: jakie skuteczne rozwiązania znaleźć, aby osób bezdomnych/ /bezrobotnych/bezradnych było mniej? Podkreśliła również konieczność autentyczności, a nie pozorowania działań pomocowych wobec osób potrzebujących.

Zagadnienia twórczości codziennej i wybitnej podjęła w swojej prelekcji dr Monika Modrzejewska-Świgulska z UŁ w Łodzi. Ukazując rysy biograficzne znanych twórców, zwracała uwagę także na ich pomysłowość realizującą się w codziennych działaniach. Po raz kolejny tego dnia postawiona została teza o złożoności definicyjnej i strukturalnej zjawiska pojmowanego jako twórczość. W prezentacji pojawiły się też ciekawostki z życia wybitnych twórców, np. Wisławy Szymborskiej. Słuchacze konferencji mieli m.in. okazję wymyślić własne „Lepiej”, czyli specyficzną, rymowaną formę przekazu, szczególnie ulubioną przez Noblistkę - słynącą nie tylko z twórczości literackiej - ale i z poczucia humoru ${ }^{4}$ (LEPIEJ PRZYJECHAĆ NA/O KREATYWNOŚCI KONFERENCJĘ, NIŻ ZALICZYĆ NA TAKIM SPOTKANIU ABSENCJĘ - dop. Z.O.).

4 Wątek związków między kreatywnością oraz twórczością i humorem podnoszony był również w pytaniach studentów. Zagadnienie to opracował w swoim posterze dr Przemysław Grzybowski z UKW w Bydgoszczy. 
O procesach poznawczych w twórczości mówił - również z wykorzystaniem Skype’a - dr Krzysztof T. Piotrowski z UJ w Krakowie. Okazało się, że zagadnienia ważne i trudne (uwaga, spostrzeganie, skojarzenia itd. a twórczość) można przekazać słuchaczom - korzystając z prezentacji multimedialnej online - w sposób przystępny, klarowny i, co podkreślało wielu studentów, „fascynujący”.

W bloku „kreatywność a doradztwo zawodowe” jako pierwszy głos zabrał Jan Giza - student z UJ w Krakowie. Przytaczając ciekawe wyniki badań, prelegent zaprezentował mechanizmy, związki i skutki kreatywności w rekrutacji zawodowej.

Praktyczny aspekt wykorzystania własnej kreatywności w poszukiwaniu pracy przedstawiła mgr Katarzyna Cukierska - doktorantka UJK, w prelekcji KREATYWNOŚĆ, PRZEDSIĘBIORCZOŚĆ - WYMÓG DZISIEJSZEGO RYNKU PRACY, NOWY TREND NA STAŁE CZY CHWILOWA MODA?

O prelekcję nawiązującą do pytań z działu „kreatywność a samokształcenie" poproszona została dr Dorota Ciechanowska z WSH TWP w Szczecinie. W wystąpieniu MAPY UMYsŁoWE JAKo sPosóB WIZUALIZACJI WIEDZY STUDENTA UŁATWIAJĄCY GŁĘBOKIE UCZENIE SIĘ słuchacze mogli dowiedzieć się, jakie są mechanizmy porządkowania i utrwalania wiedzy oraz budowania skojarzeń w metodzie mind mapping.

Tematyka kreatywności w pracy nauczyciela, ale tym razem w doświadczeniach edukacyjnych z Macedonii, powróciła w wystąpieniu mgr Joanny Gjorgievskiej z UTH w Radomiu. Prelegentka zwróciła uwagę na potrzebę poszukiwania wzorów/mentorów twórczości, którzy mogą być dla młodych ludzi ważnym czynnikiem nie tylko obrazującym, czym jest twórczość, ale i motywującym do pracy nad sobą oraz do rozwijania umiejętności rozwiązywania problemów, co z kolei stanowi antidotum wobec bezradności leżącej u podłoża wielu negatywnych zjawisk społecznych.

Jako ostatnia w bloku prelekcji wystąpiła mgr Lidia Pasich ze Świętokrzyskiego Centrum Doskonalenia Kształcenia Nauczycieli w Kielcach. Mówiąc o tym, JAK SKUTECZNIE POBUDZAĆ WYOBRAźNIĘ?, zaprezentowała również programy edukacyjne skierowane do dzieci i młodzieży, ukierunkowane na rozwijanie kreatywności w myśleniu i działaniu.

\section{Dlaczego warto angażować studentów w działania naukowe i organizacyjne...}

W konferencji STO PYTAŃ o KREATYWNość połączone zostały - na wielu płaszczyznach - działania studentów i wykładowców/profesjonalistów. Studenci - zapisując nurtujące ich pytania o kreatywność - stworzyli kanwę 
wystąpień dla prelegentów nie tylko z uczelni wyższych, ale również z innych instytucji zajmujących się działalnością edukacyjną i terapeutyczną. Towarzysząca obradom plenarnym galeria posterów pokazała, że obok siebie mogą na równych prawach pojawić się prace wykładowców i studentów, a bariera związana z różnicami implikowanymi stopniami naukowymi nie istnieje w takiej formule wypowiedzi.

Angażowanie studentów w organizację konferencji jest przykładem autentycznego wcielania w życie idei podmiotowości w kształceniu akademickim. Wykładowca i student, współpracując ze sobą na różnych etapach przedsięwzięcia, mają okazję nie tylko lepiej się poznawać, ale również widzieć w sobie nawzajem - po prostu, a może przede wszystkim - człowieka, który ma swoje pasje i zamierzenia, ale może mieć również chwile zwątpienia i słabości. To również okazja do wspólnego, twórczego poszukiwania pomysłów na rozwiązanie różnego rodzaju problemów. Bezcenna i nieprzeliczalna na żadne „punkty” jest również atmosfera takiej współpracy oraz towarzysząca jej radość i energia.

Realne działania podejmowane na rzecz wspólnego rozwoju wiedzy i gromadzenia doświadczeń $w$ ramach kształcenia uniwersyteckiego mogą także pomóc nauczycielom akademickim zapomnieć - choć na chwilę - o zniechęcających nieraz do pracy zasadach „rankingowania liderów”, czy też wymogach do awansu naukowego, w których szuka się "algorytmu” pozwalającego „obiektywnie” ocenić dorobek naukowy i osiągnięcia dydaktyczne wykładowców. Człowiek i jego praca nie składają się z samych tylko cyfr. Dopóki więc nie będziemy maszynami pracującymi według zaprogramowanego systemu liczbowego, warto podejmować działania, które udowadniają nam i innym, że będąc nauczycielami akademickimi pozostaliśmy po prostu - a może przede wszystkim - ludźmi, zdolnymi do współpracy, empatii i tworzenia...

\section{BIBLIOGR AFIA}

Dudzikowa M., Wawrzyniak-Beszterda R., Jaskulska S., Marciniak M., Bochno E., Bochno I., Knasiecka-Falbierska K., Oblicza kapitału społecznego uniwersytetu: diagnoza, interpretacje, konteksty, Oficyna Wydawnicza Impuls, Kraków 2013.

Idea uniwersytetu: reaktywacja, P. Sztompka, K. Matuszek (red.), Wydawnictwo Uniwersytetu Jagiellońskiego, Kraków 2014.

Kozielecki J., Psychotransgresjonizm: nowy kierunek psychologii, Wydawnictwo Akademickie Żak, Warszawa 2007. 


\section{SUMMARY}

Around the conference One Hundred Questions About Creativity, that is why it is worthy to engage students in scientific and organisational activities

The article contains the report of scientific conference ONE HUNDRED QUESTIONS ABOUT CREATIVITY and the analysis of reasons why it is worthy to encourage and engage students in organization of diversified scientific initiatives. In such forms of activities students and academics become real partners in the process of acquiring knowledge and experience. These activities constitute not only the opportunity for real creativity and multilateral transgressions, but also the university community that is great and uncontested value and tradition.

KEY WORDS: scientific conference, creativity, students-academics cooperation. 